\title{
Completing Accounting to Develop Cooperative Economic in Vietnam in the Digital Economic Era
}

\author{
Ngoc Mai T., Le \\ Falcuty of Auditing and Accounting \\ Hanoi University of Industry \\ Hanoi, Vietnam \\ lethingocmai@haui.edu.vn
}

\author{
Dieu T., Nguyen \\ Bac Giang Provincial People's Committee \\ Bac Giang, Vietnam \\ dieuaof@gmail.com
}

\begin{abstract}
Collective economy, with the core being cooperatives, is one of the four important economic components in the socialist-oriented market economy in our country. Developing a cooperative model is really important in the latest period, the digital economy, because this is an economic model that attracts farmers, individual economic households, individuals and many organizations, helping to restructure agriculture, build a new countryside, develop the country in a new direction, in accordance with objective laws. However, in order to develop the cooperative model according to its potential and ensure the distribution of benefits among its members and fulfill tax obligations to the state, the accounting work needs to be perfected. So that the management, the use of financial resources of the cooperative is done properly, sufficiently, transparently and objectively in accordance with the law. In fact, the accounting work under the cooperative model in Vietnam still has many weaknesses. The author has summarized, analyzed and given some specific solutions to improve the accounting work at the cooperative in the coming time.
\end{abstract}

Index Terms-Cooperative accounting, digital economy, collective economy.

\section{INTRODUCTION}

$\mathrm{C}$ OOPERATIVE is a collective economic organization, has legal status and has at least 7 members. In Vietnam, cooperatives play an important role in creating jobs and income for households and individuals. In recent years, along with the development of the economy, the number of cooperatives in Vietnam has changed from the old model to the new model, and the number of newly established cooperatives has increased. When transforming into a new model, cooperatives in Vietnam also have many advantages but also face many difficulties, especially in the organizational structure and accounting work of the cooperatives. Many cooperatives have been able to reduce input costs, improve product quality, provide stable income for members, eliminate hunger and reduce poverty, and contribute to social security for localities.

Currently, with the application of the new law on cooperatives in Vietnam, cooperatives must comply with new regulations on organizational structure and operating, requirements on charter capital, accounting structure and conditions of accountants. The cooperative accounting work must comply with the new accounting system applied exclusively to cooperatives. The quality and performance of cooperatives are greatly influenced by the results of the cooperative accounting organization. The application of new regulations as well as the influence of the digital economy also bring cer- tain challenges for cooperative accounting to help develop the cooperative economy in the digital economy.

In this study, the contributions and current status of the cooperative economy are presented to the Vietnamese economy. The article also presents the influencing factors and current status of accounting work in cooperatives. From that, the article summarizes, analyzes and offers solutions to improve the accounting work of cooperatives in the context of the digital economy.

\section{Overview Of Cooperative}

A cooperative is a collective, co-ownership economic organization, having the legal person status, voluntarily established by at least seven members who mutually cooperate in production, business and job creation to meet the common needs of cooperative members, on the basis of self-control, self-responsibility, equality and democracy in the management of the cooperative [1].

Cooperatives have been an effective way for people to exert control over their economic livelihoods as they play an increasingly important role in facilitating job creation, economic growth and social development. To be effective and successful, cooperatives must continuously achieve two inter-related goals: enhance viability and improve ability to service its members; and remain an economically viable, innovative and competitive [2].

The contribution of the cooperative sector to the national GDP, the contribution of this sector is shown through two channels, the direct contribution of the cooperative sector to economic growth and more importantly, an indirect contribution through impact on the member's economy and individual economy. The contribution of this sector to the national GDP averages about 3.9\%/year, while the contribution of the whole economic sector, households accounts for over $30 \% / \mathrm{GDP}$ of the whole country.

Through cooperatives, people associate and take advantage of natural and social conditions, traditional crafts, and local key products, and contribute capital to organize production and provide services that are not performed by a single individual. The cooperative economic sector is also an important nucleus in new rural construction, restructuring agriculture, industry, trade and service. Cooperatives create driving force for sustainable socio-economic development; the quality of the growth is stable, the job creation ability of this 
area has increased sharply; improve the quality of life of members and communities, limit negative manifestations, moral degradation.

In addition to economic contributions, the cooperative sector also plays a very important role in politics, security and society in the community. First of all, cooperatives are an important channel in creating jobs, increasing incomes for members and employees, contributing to hunger eradication and poverty alleviation, especially in the fields of agriculture and rural areas. In addition, with the spirit of "cooperation" in the cooperative, the spirit of solidarity and mutual help among members and residential communities is promoted, cooperative members expand community activities, help mutual assistance in production and business activities and improvement of cultural life. Cooperative development will promote and spread the good values of the cooperative to the whole society, such as counting; honesty, fairness, democracy, publicity, transparency, spirit of mutual help, sense of autonomy, responsibility, sense of community care, have great significance in the cause of rich people in the country strong, democratic, just and civilized society.

Developing the cooperative economy contributes to the development of community culture, strengthening political security and social order and safety in the area. Through cooperatives, gradually strengthen democracy in the management of economic organizations in particular and in the local people's life in general. Many cooperatives actively participate together with local authorities in building rural infrastructure, public welfare works, such as traffic, electricity and water systems, schools, kindergartens, medical stations, etc.

The cooperative actively participates in the process of industrialization and modernization, which is an important premise for democratization and civilization improvement in rural areas, especially in remote and isolated areas.

A cooperative is a collective economic organization that plays an important role in socio-economic development. In Vietnam, the Law on Cooperatives (2012) [3] was introduced, creating a great impetus for the development of both the size, quantity and quality of cooperatives. As of December 31, 2020, the whole country has 119,248 Cooperatives $(40,354$ Cooperatives in the agricultural sector and 78,894 Cooperatives in non-agriculture), an increase of 10,960 Cooperatives (about 10\%) compared to December 31, 2016, attracting 1,665,271 members participating members (on average, a Cooperatives has about 14 members). The number of regular employees in Cooperatives is about 1,091,015 people, an increase of 2.38 times compared to 2016 (Summary from reports of 26/63 locatities). The average revenue of a Cooperative is 523 million VND/year, up $28 \%$ compared to 2016 (Summary from reports of 41/63 locatities). The average profit of a Cooperative is 84.51 million VND/year, an increase of 1.57 times compared to 2016 (Summary from reports of $42 / 63$ locatities). In recent years, the growth rate of Cooperatives have tended to increase, with an average growth rate of $2.44 \% / y e a r$ in the $2016-2020$ period. The number of cooperatives (cooperatives) by the end of 2020, there are 26,112 cooperatives nationwide, an increase of 6,225 cooperatives (about 31.3\%) compared to 2016 (of which the number of cooperatives operating in the agricultural sector is 17,462 cooperatives, non-commercial cooperatives). agriculture is 8,650 cooperatives). The total number of members participating in the cooperative is over 6.1 million members, a decrease of 410,295 members (about 6.2\%) compared to 2016. By the end of 2020, there were 100 cooperative unions across the country (57 agricultural cooperative unions and 43 non-agricultural cooperative unions), a double increase compared to 2016. The contribution of the cooperative economy has been shown over the years through the improvement of the household economy, creating jobs for many people in society, providing stable income, and contributing to social security local.

However, because cooperatives started off as small, odd and gradually developed, there will be many limitations for cooperatives to operate in a new way, especially for accounting work at cooperatives. In addition, operating according to the organizational mechanism and operating regulations, the cooperative accountant must still comply with the general provisions of the accounting law. The accounting work in the cooperative has a great influence on tracking the scale of operations, the development of the cooperative in cash, managing cash flow and ensuring the distribution of benefits among the members of the cooperative. Therefore, in the coming time, to ensure that the cooperative will develop in accordance with the orientation of the Party and the State, the accounting in Cooperatives needs to be completed in accordance with the provisions of the Law.

\section{METHODOLOGY}

Applying the method of collecting secondary data on documents related to the influence of the digital economy on the accounting profession and the cooperative economy, the current status of cooperative accounting in Vietnam through data of the General Statistics Office, scientific articles, economic journals, internet, reports, seminars with related topics. Collected data is statistically, aggregated, and analyzed to clarify the operational status of the cooperative economic model and cooperative accounting work in Vietnam in the current industrial revolution 4.0 period, from that provide suitable solutions.

\section{OPERATIONAL STATUS OF COOPERATIVE}

A. Current status of cooperative economic activities in Vietnam

The promulgation of the Law on Cooperatives in 2012 created a legal corridor to promote the development of the cooperative economic sector in Vietnam. The Steering Committee for economic renewal and development of cooperatives has been built and well organized to perform the tasks as prescribed at all levels. Vietnam is currently a member of the World Trade Organization (WTO) since 2017, participating in 13 free trade agreements, especially CPTPP, EVFTA and IPA. In the globalization trend and the influence of the industrial revolution 4.0, the world tends to use high- 
quality products with clear origin, which requires cooperatives to make changes to adapt. Applying e-commerce or digital economy is considered as a solution to help cooperatives improve their competitiveness and expand markets. International integration and revolution 4.0 are both opportunities and challenges for the development of the cooperative economy in Vietnam.

In Vietnam, the number of active cooperatives with annual average production and business results in the period 20162019 of the whole country is 13,642 cooperatives, an increase of 5.0\% compared to the average period of 2011-2015. Specifically as follows: In the period 2016-2019, there are 5 localities leading the country in the average number of cooperatives, including Hanoi 1,308 cooperatives (down 4.5\% compared to the annual average in the period 2011-2015); Ha Tinh 979 cooperatives (up 72.9\%); Thanh Hoa 721 cooperatives (down $0.9 \%$ ); Nghe An 490 cooperatives (down 2.6\%); Hai Duong 458 cooperatives (down 11.3\%). There are $29 / 63$ localities with an increase in the number of active cooperatives whose average production and business results in the 2016-2019 period are higher than the national growth rate (up 5.0\%) compared to the average in the 2011-2015 period. . In which, 15/63 localities had an increase of over $30 \%$, including: Son La with an increase of $295.0 \%$; Binh Phuoc increased by $107.7 \%$; Bac Kan increased by $90.5 \%$; Quang Ninh increased by $81.7 \%$; Kien Giang increased by $79.5 \%$; Lam Dong increased by $75.9 \%$; Ha Tinh increased $72.9 \%$; Lang Son increased by $67.4 \%$; Dong Nai increased by $61.5 \%$; Dak Lak increased by $54.1 \%$; Thai Nguyen increased by $53.6 \%$. There are 8/63 localities with an increase in the number of active cooperatives whose average production and business results in the 2016-2019 period are lower than the national average growth rate in the 2011-2015 period. There were 26/63 localities where the average number of cooperatives in the period 2016-2019 decreased compared with the average in the period 2011-2015, of which 7 localities decreased by more than $15 \%$, including: Bac Ninh down 34.7\%; Hoa Binh down 31.9\%; Ha Giang decreased by $26.1 \%$; Cao Bang down 24.0\%; Binh Thuan down 18.5\%; Khanh Hoa decreased by $17.8 \%$; Phu Yen decreased by $15.9 \%$ [4].

TABLE I

Number of acting cooperatives having business by province

Cooperative, \%

\begin{tabular}{|c|c|c|c|c|c|c|c|}
\hline & \multirow[b]{2}{*}{$\begin{array}{c}\text { Period } \\
\text { Avera- } \\
\text { ge } \\
2013- \\
2015\end{array}$} & \multirow[b]{2}{*}{2016} & \multirow[b]{2}{*}{2017} & \multirow[b]{2}{*}{2018} & \multirow[b]{2}{*}{2019} & \multicolumn{2}{|c|}{$\begin{array}{c}\text { Development } \\
\text { index }\end{array}$} \\
\hline & & & & & & $\begin{array}{c}2019 \\
\text { vs } \\
2018\end{array}$ & 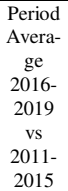 \\
\hline $\begin{array}{c}\text { WHOLE } \\
\text { COUNTRY } \\
\end{array}$ & 12991 & 13012 & 13226 & 13958 & 14388 & 103.1 & 105 \\
\hline Red River Delta & 4928 & 4511 & 4466 & 4507 & 4511 & 100.1 & 93.1 \\
\hline $\begin{array}{l}\text { Northern midlands } \\
\text { and mountain areas }\end{array}$ & 2184 & 2061 & 2160 & 2376 & 2540 & 106.9 & 104.5 \\
\hline $\begin{array}{l}\text { North Central and } \\
\text { Central coastal areas }\end{array}$ & 3501 & 3788 & 3791 & 3919 & 3903 & 99.6 & 110 \\
\hline Central Highlands & 407 & 460 & 535 & 643 & 726 & 112.9 & 145.3 \\
\hline South East & 740 & 861 & 906 & 1038 & 1057 & 110.8 & 130.4 \\
\hline
\end{tabular}

\begin{tabular}{|l|l|l|l|l|l|l|l|}
\hline Mekong River Delta & 1232 & 1331 & 1368 & 1475 & 1651 & 111.9 & 118.1 \\
\hline
\end{tabular}

On average, in the 2016-2019 period, the cooperative operating with production and business results nationwide attracted 188,637 employees, down $14.3 \%$ compared to the average in the 2011-2015 period. In the period 2016-2019, there are 4 localities that attract an average of over 10,000 employees/year to work in active cooperatives, including: Hanoi 18,695 employees (down 17.7\% compared to the average year in the period 2011-2015). ); Ho Chi Minh City 14,719 employees (down 30.0\%); Thanh Hoa 10,390 employees (down 25.5\%); Ha Tinh has 10,006 employees (up $65.2 \%$ ). On average, in the period 2016-2019, 12/63 localities have an increase in the rate of attracting labor to work in active cooperatives compared to the average in the 2011-2015 period (the national average decreased by $14.3 \%$ ). ), in which 9 localities had an increase of over $20 \%$, including: Son La with an increase of $195.0 \%$; Binh Phuoc increased $87.9 \%$; Kien Giang increased by $81.7 \%$; Bac Kan increased by $66.2 \%$; Ha Tinh increased $65.2 \%$; Lam Dong increased by $62.5 \%$; Bac Lieu increased by $46.6 \%$; Hau Giang increased by $43.8 \%$; Tien Giang increased by $39.4 \%$. There are 35/63 localities with the speed of attracting labor to working cooperatives with the average production and business results in the 2016-2019 period compared with the average in the 2011-2015 period, which is lower than the national average., in which 7 localities have the rate of attracting labor to work in cooperatives decreased by over 30\%, including: Phu Yen down 46.9\%; Ha Nam down 43.8\%; Hai Phong down 42.9\%; Bac Ninh down 40.0\%; Lao Cai decreased by $35.6 \%$; Khanh Hoa decreased by $32.5 \%$; Tuyen Quang fell 32.2\% [4].

TABLE II

Number of employees in acting cooperatives having business by province

\begin{tabular}{|c|c|c|c|c|c|c|c|}
\hline & \multirow[b]{2}{*}{$\begin{array}{c}\text { Period } \\
\text { Avera-ge } \\
2013- \\
2015\end{array}$} & \multirow[b]{2}{*}{2016} & \multirow[b]{2}{*}{2017} & \multirow[b]{2}{*}{2018} & \multirow[b]{2}{*}{2019} & \multicolumn{2}{|c|}{$\begin{array}{l}\text { Development } \\
\text { index }\end{array}$} \\
\hline & & & & & & $\begin{array}{c}2019 \\
\text { vs } \\
2018\end{array}$ & $\begin{array}{c}\text { Period } \\
\text { Avera- } \\
\text { ge } \\
2016- \\
2019 \\
\text { vs } \\
2011- \\
2015 \\
\end{array}$ \\
\hline $\begin{array}{c}\text { WHOLE } \\
\text { COUNTRY }\end{array}$ & 220151 & 200925 & 188612 & 185714 & 179938 & 96.9 & 85.7 \\
\hline Red River Delta & 85536 & 71735 & 69109 & 66725 & 58679 & 87.9 & 77.8 \\
\hline $\begin{array}{c}\text { Northern } \\
\text { midlands and } \\
\text { mountain areas }\end{array}$ & 26357 & 25413 & 24290 & 24762 & 25399 & 102.6 & 94.7 \\
\hline $\begin{array}{l}\text { North Central and } \\
\text { Central coastal } \\
\text { areas }\end{array}$ & 48117 & 46906 & 43090 & 42258 & 41720 & 98.7 & 90.4 \\
\hline Central Highlands & 8077 & 7090 & 6760 & 7037 & 6689 & 95.1 & 85.3 \\
\hline South East & 30755 & 28063 & 23498 & 22160 & 23432 & 105.7 & 78.5 \\
\hline $\begin{array}{l}\text { Mekong River } \\
\text { Delta }\end{array}$ & 21309 & 21718 & 21865 & 22772 & 24019 & 105.5 & 106 \\
\hline
\end{tabular}

On average, in the period 2016-2019, each year the cooperative sector generated 3,152 billion VND in pre-tax profit, an increase of $0.7 \%$ compared to the average profit earned in the 2011-2015 period. In the period 2016-2019, 60/63 localities operated with profit, of which 3 localities had an average annual profit before tax of over 100 billion VND, including: Ho Chi Minh City 1,481 billion VND (down 3.7\%) compared with the period 2011-2015), Dong Nai 198 billion (up 190.8\%) and Hanoi 185 billion (down 52.4\%). There were 
3/63 localities in the period 2016-2019 suffered losses, of which: Thai Nguyen lost 123 billion VND (in the period 20112015 lost 52 billion VND), Da Nang lost 11 billion VND (in the period 2011-2015 lost 2 billion VND). billion dong), Lao Cai lost 1 billion dong (in the period 2011-2015, the profit was 6 billion dong). Regarding the growth rate of pre-tax profit, 28/63 localities had a decrease in pre-tax profit in the 20162019 period compared to the 2011-2015 period; 35/63 localities saw an increase in pre-tax profits, of which 5 localities increased by more than 100\%, including: Son La with an increase of 365.2\%; Dong Nai increased 190.8\%; Bac Ninh increased by $156.4 \%$; Ba Ria - Vung Tau increased by 135.1\%; Nam Dinh increased 104\% [4].

TABLE III

Profit before taxes of acting cooperatives having business by province

Bill. dongs, $\%$

\begin{tabular}{|c|c|c|c|c|c|}
\hline & & & & \multicolumn{2}{|c|}{$\begin{array}{c}\text { Development } \\
\text { index }\end{array}$} \\
\cline { 4 - 6 } & $\begin{array}{c}\text { Period } \\
\text { Average } \\
2011- \\
2015\end{array}$ & 2018 & 2019 & $\begin{array}{c}2019 \\
\text { vs } \\
2018\end{array}$ & $\begin{array}{c}\text { Averiod } \\
2016- \\
2019 \text { vs } \\
2011- \\
2015\end{array}$ \\
\hline $\begin{array}{c}\text { WHOLE } \\
\text { COUNTRY }\end{array}$ & 31129 & 2568 & 2663 & 103.7 & 100.7 \\
\hline Red River Delta & 617 & 450 & 429 & 95.3 & 82 \\
\hline $\begin{array}{c}\text { Northern midlands } \\
\text { and mountain areas }\end{array}$ & -54 & -126 & -117 & & \\
\hline $\begin{array}{c}\text { North Central and } \\
\text { Central coastal areas }\end{array}$ & 363 & 266 & 148 & 55.6 & 78.8 \\
\hline Central Highlands & 96 & 144 & 135 & 93.8 & 147.7 \\
\hline South East & 1680 & 1581 & 1529 & 96.7 & 106.3 \\
\hline Mekong River Delta & 428 & 253 & 539 & 213 & 103.4 \\
\hline
\end{tabular}

To sum up, the number of cooperatives in Vietnam tends to increase, but the number of participating workers decreases in general. Profits from acting cooperatives have generally increased in the current period. The influence of the industrial revolution 4.0 and the trend of globalization will bring new development directions to the cooperative economy. Therefore, the cooperative economy needs appropriate changes to capture development opportunities.

B. Organizational structure, operational apparatus of the cooperative economic model

Cooperative is a collective economic organization, jointly owned, with legal status, established by at least 7 members voluntarily and cooperates and supports each other in production, business and job creation activities. in order to meet the common needs of members, on the basis of autonomy, self-responsibility, equality and democracy in cooperative management [3].

According to the provisions of the Law on Cooperatives 2012, the organizational structure of cooperatives and unions of cooperatives consists of a general meeting of members, a board of directors, a director (general director) and a supervisory board or controller.

The Members' General Assembly has the highest decisionmaking power of cooperatives and unions of cooperatives. The general meeting of members consists of the annual general meeting of members and an extraordinary general meeting of members. The general meeting of members is held in the form of a general meeting or a general meeting of delegates (hereinafter referred to as the general meeting of members). Powers and duties of the general meeting of members are entitled to decide on the following contents: "report on activities, finance, income, salary of members, decide on the expansion and narrowing of the operation scale of the cooperative, deciding key positions in the cooperative...." [3].

The Board of Directors of cooperatives and unions of cooperatives is the governing body for cooperatives and unions of cooperatives established by conference or general meeting of members to elect, relieve from duty or dismiss by secret ballot. . The Board of Directors consists of the chairman and members, the number of members of the Board of Directors is prescribed by the charter but the minimum is 3 people, the maximum is 15 people.

The term of office of the Board of Directors of the cooperatives and unions of cooperatives shall be prescribed by the charter of the cooperatives and unions of cooperatives, but shall be at least 02 years and the maximum is 05 years. The Board of Directors uses the seal of the cooperatives and unions of cooperatives to perform its rights and duties. Decisions and tasks of the Board of Directors "is the advisory body to help the General Assembly of Members implement the planned work, evaluate the performance of the divisions and report to the General Meeting of Members. ..."

The Supervisory Board and supervisors operate independently, inspect and supervise the activities of cooperatives and unions of cooperatives in accordance with the provisions of law and the charter. The Supervisory Board or controller shall be directly elected by the general meeting of members from among the members and representatives of the affiliated cooperatives by secret ballot. The number of members of the Supervisory Board shall be decided by the general meeting of members but must not exceed 07 people. Cooperatives with 30 or more members and unions of cooperatives with 10 or more member cooperatives must elect a supervisory board. For cooperatives with less than 30 members, unions of cooperatives with less than 10 member cooperatives, the establishment of a supervisory board or controller is prescribed by the charter. The head of the Supervisory Board is directly elected by the general meeting of members from among the members of the Control Board, the term of the Supervisory Board or the controller according to the term of the Board of Directors.

\section{Operational status of the cooperative accounting apparatus} in Vietnam

First, about the organization of the accounting apparatus: The organization of accounting work in a cooperative can be understood as the building and establishment of a reciprocal relationship between accounting objects, accounting methods, the accounting apparatus in accordance with the provisions of the law. Currently, the cooperative's accounting work is carried out in accordance with the provisions of Law on Accounting 
88/2015/QH13 dated November 20, 2015 [5] and Circular No. 24/2017/TT-BTC dated March 28, 2017 of the Ministry of Finance [6] on guiding the accounting regime of cooperatives and unions of cooperatives. Particularly for large-scale cooperatives with many transactions that are not regulated in Circular No. 24/2017/TT-BTC, they may choose to apply the accounting system for small and medium-sized enterprises (SMEs) promulgated in accordance with this Circular. No. 133/2016/TT-BTC dated August 26, 2016 of the Ministry of Finance [7]. If the cooperative chooses to apply the accounting method according to this Circular, it must comply with all provisions of this Circular, if there are arising transactions not specified in Circular 24/2017/TT-BTC. The choice to apply the accounting regime must be made consistently in the fiscal year and must be reported to the tax authority managing the cooperative.

In the current actual situation, the organization of the accounting apparatus mostly complies with Circular No. 24/2017/TT-BTC, because the scale of operation of the cooperative is still small and has not yet developed to an enterprise level. According to regulations, the organization of the accounting apparatus is the arrangement and assignment of work for each accountant and the organization of rotation of documents in the accounting department of the cooperative. An accountant does all the work, even concurrently serving as a storekeeper and treasurer, so mistakes and mistakes that are difficult to detect still occur and violate the principle of nonduality.

Second, on the approach and application of the accounting regime. At present, many cooperatives do not fully grasp the basic principles of accounting prescribed in the Law on Accounting and the Accounting System, as well as the guidelines, which leads to many mistakes in accounting work, which is not consistent with the law regulations, affecting the tax payment of enterprises and the distribution of benefits among members of the cooperative.

Third, the application of accounting vouchers, according to regulations, each arising economic transaction must have a specific set of vouchers to ensure the authenticity and accuracy of the operation taking place in accordance with the operating functions of the Cooperative, in accordance with the implementation schedule. However, most cooperatives do not design strict vouchers in reality. There are many shortcomings leading to ineffective management of financial activities, possible tax fraud, status. This will seriously affect the socioeconomic development of the country.

Fourth, organize of initial data collection of economic transactions arising in the cooperative. Although cooperatives have compliance with regulations on accounting documents, they have not paid much attention to building a specific scientific document circulation process. This affects the quality of accounting information at the unit. Beside, the distinction and identification of vouchers made to record books for each object is not really clear. Many accountants have used data in one accounting book as a basis for recording in other accounting books. When performing period-end transactions, most accountants do not prepare vouchers reflecting endogenous economic transactions, but transfer data based on detailed books. This violated basic accounting principles.

Fifth, apply of the accounting system. The task of each accountant is that, after basing on each arising economic transaction, it is necessary to make accounting entries of arising transactions and in accordance with the law, ensuring the monitoring, consistency and binding relationship with other accounts. However, due to the lack of understanding of the nature, use and structure of each accounting account, most accountants at cooperatives use accounting accounts incorrectly for specific situations and record business transactions is not in accordance with the prescribed regime. In detail, in the accounting work of cost aggregation and costing, the cooperative accountant must perform such operations as: Cost aggregation, cost allocation, cost summation, cost calculation, etc. Transactions must be reflected on a specific account according to its nature, but many accountants do not distinguish the use of groups of accounts in the "business account" type such as: "group of accounts for cost calculation" and "group of accounts for distribution according to estimates". This affects the accounting's reflection and recording and the calculation and determination of the necessary criteria to provide information for management and operation of production and business activities.

Sixth, the state of making accounting statements and financial statements at the accounting apparatus of the cooperative, although it is correct in the form for the applicable accounting system but there are still many errors. The balance between the not correct, the account with outstanding balance and credit balance is still not true to reality. There is still an account with no balance but still hanging on the accounting books. In the recognition of accounting information on the financial statements, there are also some errors in the recognition of incorrect items on the accounting reports such as not distinguishing between social insurance and health insurance as debt, liabilities or equity. The presentation of indicators, codes of indicators are not recorded in the correct order. When recognizing payments that do not fully comply with the principles of financial statement presentation.

Seventh, organize the accounting inspection. In fact, because the accounting apparatus in cooperatives usually has one person, the leadership and management of the cooperative are often people who do not have expertise in finance accounting, leading to the organization of accounting inspection in the cooperative. There are many shortcomings, it is difficult to detect errors in accounting work. Only when there is a tax agency, an audit agency can detect the error, but then it will be more difficult to handle the mistake when it is detected internally from the beginning. In addition, cooperatives often have a small scale of operation, with little economic activity, so many cooperatives believe that they only focus on the responsibility of the Board of Directors for the use of capital, revenues, expenses and profit distribution without focusing on checking the order of recording arising 
economic transactions, vouchers, book-keeping and making accounting reports. This has lead to gaps in inspection and control are the causes of errors in accounting work at cooperatives.

Eighth, the application of information technology in accounting activities at the cooperative, the establishment of the cooperative was initially small, so in each cooperative, a large amount of concentrated financial resources were always devoted, focusing on the development of production and business without investing in infrastructure and facilities for accounting work at cooperatives. So most of the application of information technology to handling cooperative work is still very limited, monitoring on software Accounting is not yet universal, some units still use excel to do accounting work, leading to confusion of accounting information and limited accounting information storage [8]. A number of cooperative alliances have invested in purchasing accounting software [9] such as accounting software BUCA, Lotus, DTSoft, EBIC.CPA, WACA, VCS-PADDY in the provinces. The cooperatives deployed training for accountants in cooperatives to apply accounting software in practice. However, there are few cooperatives in provinces use this software to handle accounting work. The reason is that it is difficult for accountants to access and apply the software used for accounting work. On the other hand, software providers such as BUCA only provide operating instructions with general principles, so accountants do not know how to use the software to process existing accounting data. Therefore, accountants in the cooperatives mainly perform manual accounting or combine excel at the present.

Final, the qualifications of accountants in cooperatives are still limited. Currently, accountants in some cooperatives still have limited qualifications, thus hindering the absorption and application of new changes in accounting. Most of the accountants in cooperatives have not been professionally trained, only $50 \%$ have professional qualifications, of which $20 \%$ have intermediate or higher degrees. The professional training for accountants has not been paid enough attention. Many business cooperatives are inefficient or newly established, so there is little funding, low salary payments for accountants, thus not creating motivation for accountants to study and improve their qualifications. Many cooperatives cannot afford to send accountants to train and improve their accounting professional qualifications. This has led to difficult for accountants to apply new policies and procedures and apply digital technology to their accounting work.

D. Factors affecting the accounting work of Cooperatives

First, the influence of the cooperative's perception. For cooperatives, the financial management is in accordance with the accounting regime, ensuring honesty and objectivity, forming financial sources, using financial sources, distributing incomes to members, and fulfilling tax obligations with cooperatives. The state is still new, the mentality is "difficult to adapt" or "unfamiliar", many HXT officials still have to take a long time to adapt. It is very difficult to manage the finances properly with the accounting regime without affecting the interests of individuals in the cooperative. .

Second, due to the transformation of the management apparatus according to new regulations, the management in general and the organization of accounting work in particular faced many difficulties during the transformation.

Third, the barrier of accounting human resources. In cooperatives, the accounting qualifications of accountants do not meet the actual requirements, plus the double duty of many tasks, so the handling of accounting situations still has many errors.

Fourth, due to the barrier to mobilizing financial resources to develop the cooperative model, in order to supply products that meet the requirements of the market, it is necessary to invest a lot of input costs for production and implementation. Creating a satisfactory product requires a lot of capital. The allocation of capital to invest in the development of the accounting system will not be prioritized, so the accounting work at the cooperative has not been developed with the development of the operation scale.

Fifth, the accounting system and regulations related to the organization of work often change, but the qualifications of the accountants are still limited. So the access to new knowledge and regulations is slow. This affects the operation of the cooperative.

\section{SOLUTIONS}

In the context of society's rapid development of science and technology, the era of the digital economy, the requirements for the quality of services and products are increasing, the competition in the market is getting fiercer. Competition on integration and trade liberalization of agricultural, forestry and fishery products with other countries is increasing, so the products supplied to the market by the cooperative will have to face stiff competition from other countries. Therefore, in order to survive and develop, it is necessary to have a solid, professional and highly qualified accounting department. In addition to recording and monitoring arising economic transactions, it is necessary to have advice on the development policy of the cooperative to ensure compliance with the provisions of the law, generate large profit after tax, assess the impact of the cooperative's growth of the cooperative through annual financial statements and the influence of other economic factors. In the article, the author offers some specific solutions to focus on accounting, ensuring ensure the highest operational efficiency of the accounting apparatus in the cooperative.

First, perfect the organization of the accounting apparatus. The operational efficiency of accounting work in cooperative depends on the organization of the accounting apparatus [10]. Therefore, when a cooperative is newly established, it is necessary to clearly define the scale of its operations to determine the appropriate accounting regime according to Circular No. 24/2017/TT-BTC or Circular No. 133/2016/TTBTC [11]. From there, it will determine the number of accounting departments and the number of people working in each department. The number of accounting departments in the 
cooperative should be determined appropriately to ensure the working relationship between these departments in common with all other departments in order to assign and coordinate the responsibilities of each department in handling work, meeting requirements and reporting information for management of the cooperative. The cooperative's accounting apparatus is organized according to a centralized accounting model to match its operational characteristics. Accounting jobs need separation of responsibilities to ensure the ability to control accounting work as well as easier to detect errors.

Second, perfecting the accounting voucher system. The perfecting the accounting voucher system for accounting operations is very important. The cooperative needs to set up accounting vouchers according to each arising economic operation, ensuring compliance with regulations, logic, objectivity, science, easy to check, compare errors. In addition, it is necessary to strengthen the inspection, supplement and amend the unreasonable accounting process so that the circulation of documents is carried out in accordance with regulations. The initial collection of documents should be suitable to the scale of operation and management requirements of each type of business of the cooperative. For each cooperative, it is necessary to build an appropriate document system and the document rotation process associated with the responsibilities of each individual and department to strictly control as well as help the circulation of documents to be avoid overlapping between parts. Cooperatives should apply digital technology in issuing, recording and managing accounting vouchers.

Third, perfect the organization of the accounting system. It is very important to identify the correct account to account for arising economic operations, to balance the accounts, to make accounting books, to serve the reporting of financial resources, to inspect and control agencies. State management agencies, so accountants need to accurately determine the account before accounting, so as to best reflect the arising economic operations. For example, the cooperative accounting that aggregates production costs on account 632 is inconsistent with the nature of the current account. According to the provisions of Circular No. 24/2017/TT-BTC [6], to collect costs and calculate costs, accountants must use a group of costing accounts including account "Account 154 - Production and business expenses"; "Account 2422 - Construction in progress". When discharging materials and costs related to production services, the accountant must use account 154 to reflect, at the end of the period, to summarize and calculate the cost. In case, there are expenses related to many periods that need to be monitored and allocated according to the plan, the accountant must monitor and record them on the group of accounts distributed according to the estimate, including "Account 2421- Expenses for payment prior to". These costs are often incurred in cooperatives such as: The cost of major repair of the irrigation system; Cost of tools, tools used many times; The initial seedling cost is related to many crops, the initial cost of tillage. Besides using general accounts, depending on the management requirements of each unit, accountants can open more detailed accounts to serve the provision of information. The construction of a detailed account system is essential for the financial management of the cooperative and meets the requirements of providing information for internal management of the unit.

Fourth, perfecting the system of books and financial statements in accordance with regulations, opening the books according to the instructions, taking careful notes and printing the archives after each accounting period is a must. The financial statements of the cooperatives should be prepared in accordance with accounting principles, the items should be presented in the correct order, nature and codes. Receivables are not presented in detail on the Balance Sheet. In the Report on the increase and decrease of the cooperative's equity, the social insurance capital for the cooperative's employees is not presented, the nature of the source of social insurance is not business capital.

Fifth, it is necessary to support capacity building for cooperative staff in general and accounting staff in particular, with short-term training courses. Having policies to attract qualified human resources to work in cooperatives. Accountants need to be proactive in researching and updating new accounting programs and regimes. Cooperatives need to create conditions and allocate funds for training and retraining to help accountants access and use accounting software proficiently as required by the digital economy.

Sixth, perform accounting checks at cooperatives regularly to quickly detect errors. The inspection contents need to be fully detailed such as the implementation of the accounting regime on vouchers, bookkeeping, and the preparation of financial statements. Check the mobilization, use of capital, cash, increase or decrease of funds, business results.

Final, it is necessary to arrange annual capital to invest in facilities and apply information in accounting work at the cooperative. Because the application of information technology often changes, it is necessary to have a fixed financial source in order to meet the needs of the job when there is a change. Cooperatives need to promote the application of digital technology in management and administration of production, business and service activities, as well as accounting work through building a system of utilities, monitoring, and increasing internal management efficiency [12] by digital technology such as: human resource management, inventory import and export, cost valuation, selling price, production management, farming areas, batch and code management, supply chain management (packaging, transportation, storage), etc [13]. Allows to monitor, advise and guide the implementation of production processes, operations, remote manipulation, creation and termination of operations on the Japanese system. specialized electronic signature of the system; at the same time, it helps the cooperative to connect with information channels about policies, techniques, markets and units providing materials, transportation, consumption, etc. to increase business performance. Provinces should pilot cooperative models applying digital technology as a point to evaluate, learn from experience, and replicate on a large scale. 
Management agencies need to focus on effectively implementing and supporting cooperatives in applying e-commerce and applying new technologies in e-commerce, supporting the digital transformation process. Cooperatives need to invest in accounting software such as HTC-Accounting, Bavutex, DTSoft, EBIC.CPA to ensure the timeliness and accuracy of accounting data, and improve the efficiency of accounting work according to the standards. requirements of the 4.0 revolution.

\section{REFERENCES}

[1] General Statistics Office, 2020. Statistical Yearbook of Vietnam, Statistical Publishing House.

[2] Dogarawa, Ahmad Bello, (2010). The Role of Cooperative Societies in Economic Development, SSRN, June 8, 2010.

[3] Law on Cooperatives of Vietnam, No.23/2012/QH13, 2012

[4] Ministry of Planning and Investment, 2021. 2021 Vietnamese Cooperatives white book, Statistical Publishing House.
[5] Law on Accounting of Vietnam, No.88/2015/QH13, 2015.

[6] Ministry of Finance, 2017. Guiding the Accounting Regime of Cooperatives and Unions of Cooperatives, Circular No. 24/2017/TTBTC, Dated 28/3/2017.

[7] Ministry of Finance, 2016. Guiding the Accounting Regime for SME, Circular No. 133/2016/TT-BTC, Dated 26/8/2016.

[8] Le Ngoc, "The current situation of digital transformation in agricultural cooperatives and solutions in the coming time", in press.

[9] D.T. Han, 2020. Difficulty in organizing accounting work in new type agricultural cooperatives, Journal of Accounting \& Auditing.

[10] YUAN Weiqian, (2015). On Perfection of Governance Structure of Rural Cooperative Economic Organizations in China, International Business and Management, Vol. 10, No. 2, 2015, pp. 92-97, April 2015.

[11] Vietnam Academy of Agricultural Sciences, https://vaas.vn/vi/tieudiem-binh-luan/mot-so-giai-phap-hoan-thien-khung-phap-ly-ho-trophat-trien-hop-tac-xa-nong, Paper can be found at the link.

[12] N.T. Huyen, 2021. Some solutions to develop agricultural cooperatives in Vietnam today", Industry and Trade Journal.

[13] D.V. Thanh, 2020. Some solutions to develop the collective and cooperative economic sector, Financial Journal. 